It is the very qualities that make the work attractive that will prove its undoing in large, heavily used institutions. Permalife paper was not used, and this lack of permanence may result in the routing of the title to a fugitive or pamphlet collection; the visually attractive paper covers, fine for a personal bookshelf, will give way to a library or trade binding. It is most unfortunate that the producers of this report did not take as guidance many of the jurors' remarks. And the law (39 George III cap. 76) has been broken again: the place of publication and the date of publication were not included in the imprint of the copies sent to me.

\title{
Beth Miller
}

(Beth Miller is the Special Collections/Rare Books Librarian at The D.B. Weldon Library, The University of Western Ontario, London, Ontario.)

\section{BI - \& MULTI-LINGUISME / LINGUALISM}

Le bilinguisme chez l'enfant et l'apprentissage d'une langue seconde: bibliographie analytique, par Evangelos A. Afendras [et] Albertina Pianarosa. Québec Les Presses de l'Université Laval, 1975. xxiii, 401 p., $\$ 17.95$.

Ce volume est conçu pour des chercheurs de disciplines variées ainsi que pour des enseignants, administrateurs scolaires, ou parents s'intéressant à la question du bilinguisme et de l'acquisition d'une langue seconde chez l'enfant. L'essentiel $\mathrm{du}$ volume comprend une liste d'ouvrages avec, pour chaque titre, les détails bibliographiques, et des mots-clef décrivant le contenu. Ces mêmes descripteurs se retrouvent dans les index. L'index analytique principal étant précédé d'une liste des champs conceptuels majeurs, le lecteur repère assez facilement les références susceptibles de l'intéresser.

Les 1661 références regroupent des travaux - articles, livres ou documents provenant de différents pays, mais reflètent plus particulièrement la prolifération des recherches américaines des années '60 et '70. Les sources canadiennes sont représentées surtout par les recherches de Lambert, Tucker et Macnamara de l'Université McGill. On notera que cette bibliographie porte essentiellement sur des publications antérieures à 1973 , bien que les auteurs, qui préparent déjà un deuxième volume, ne soient pas explicites sur ce point.

En constituant cette bibliographie, les auteurs n'ont pas su se limiter assez dans le choix des titres qui englobent un domaine très large et des disciplines très variées. Sans doute n'est-il pas aisé de fixer de façon précise les frontières de ce qui constitue "le bilinguisme" ou "l'apprentissage d'une langue seconde". On pourrait cependant faire des réserves sur la décision d'inclure dans cet ouvrage de nombreuses références concernant le dialecte afro-américain ou sur les difficultés d'apprentissage chez l'enfant noir. Le chercheur informé n'aura pas de mal à se frayer un chemin à travers cette diversité d'informations. Le travail du néophyte aurait été facilité si les auteurs avaient cerné plus rigoureusement le domaine qu'ils cherchaient à couvrir. Il aurait été également avantageux de fournir au lecteur des indices permettant de distinguer les recherches empiriques des ouvrages théoriques, philosophiques ou autres. 
L'utilité de cette publication s'accroit du fait que l'avant propos, l'introduction ainsi que les index sont présentés en français et en anglais. Les termes descriptifs accompagnant chaque référence sont en anglais seulement.

Alison d'Anglejan

(Alison d'Anglejan - PhD, Psycholinguistique, Université McGill - est professeur adjoint à la Faculté des sciences de l'éducation à l'Université de Montréal. Son enseignement et ses recherches portent sur l'acquisition du langage, langue maternelle, et langues secondes.)

Multilingual Political Systems: Problems and Solutions/Les etats multilingues: problémes et solutions. Presented by/presenté par Jean-Guy Savard \& Richard Vigneault. Québec: Les presses de l'université Laval, 1975. (Publications of the International Center for Research on Bilingualism/Travaux du centre international de recherche sur le bilinguisme) 591 p., $\$ 16.75$.

Political and social scientists have, since the early 1960's, turned their attention to the study of politics in multilingual societies. The appearance of this publication is rather timely, for journalists spill a lot of ink outlining cogent reasons why Quebec should or should not remain in Confederation. On the other hand, the possibility of Quebec seceding from the federal structure is not even mentioned. This should give the reader an indication of how rapidly attitudes can mellow, and aspirations crystallize, in just four short years!

This book was compiled from the Round Table presentations on Multilingual Political Systems: Problems and Solutions, the theme at a conference cosponsored by the International Political Science Association and the International Center for Research on Bilingualism (Quebec, March 27 to 31, 1972). It is explained in the preface that the participants were left free to write what they wished relating to the theme of 'Multilingual Political Systems', and as a result the topics and approaches are as diverse as the membership of the I.P.S.A.

This work is divided into two main sections. The first consists of ten articles edited by the authors after the conference, and 'strung together' by the editors under general headings on varying aspects of politics in multilingual states. The second section is devoted to Case Studies of Canada, Spain, Belgium, Lebanon, Israel, British Honduras, and the Asian Federations.

No comprehensive bibliography was prepared for the book; however, all the articles except one are followed by 'notes', or explanatory footnotes, in which the authors pinpoint the references, make comparisons in different countries, and generally advance the discussion. The extensive 'notes' summarize well the sources used, and are employed by one contributor, Professor Meisel, to point the researcher-reader in new, if not always fruitful, directions.

Jacques Brazeau's article, entitled 'L'Usage des Langues dans les Activités de Travail", is'sandwiched'between Kenneth McRae's dispassionate article on "The Concept of Consociational Democracy" and John Meisel's analytical study of "Political Styles and Language-Use in Canada". Professor McRae's article includes a lengthy but well chosen bibliography, while M. Brazeau, in offering a more personal and emotionally persuasive delivery, seems to have discounted 